\title{
Ancestor worship in Korea and Africa: Social function or religious phenomenon? ${ }^{1}$
}

\author{
Choon Sup Bae \\ (University of Pretoria)
}

\section{ABSTRACT}

\section{Ancestor worship in Korea and Africa: Social function or religious phenomenon?}

Ancestor worship is a dilemma for Christian communities in Korea and Africa, who have difficulty adapting Western theology to their Third World cultures. Allan Culpepper calls ancestor worship a cultural phenomenon, not a hindrance to the Gospel message, which this article refutes. Ancestor worship is religious rather than social in function. Common features of ancestor worship in Africa and Korea are 1) conventional superstition (shamanism in Korea, animism in Africa), 2) belief in immortality, and 3) ancestor veneration/filial piety. Theological assessment reveals the incompatibility of ancestor worship with Christianity. 1) Fear of ancestors is replaced by liberation in Christ. 2) The dead exist in a mode completely different to earthly existence and have no power in the world. 3) Ancestors cannot fulfil the intermediary role reserved for the Holy Spirit. Ancestor worship should be viewed as idol worship. Contextualisation of kerygma becomes distorted when religious pluralism is tolerated.

\section{INTRODUCTION}

Niebuhr (1951:1) has pointed out that the relationship between Christ and culture has been 'an enduring problem' throughout the history of the expansion of Christianity. This 'enduring problem' is clearly illustrated when one examines the cultural dilemma that emerging Third World churches face. When westernised Christianity, which is rooted in Western thought, arrives in a different cultural sphere, it inevitably distances itself from the existing culture or works to break down this culture. Western theological ideas often stand in sharp contrast to the particular Third World cultural context, and the younger Christian churches in Third

1 This contribution is part of the research towards the author's MThdegree in New Testament Studies under the supervision of Prof. Gert J Steyn at the University of Pretoria. 
World countries are sometimes faced with perplexing dilemmas caused by radical Western theologies, which are in the Third World context not always relevant and meaningful. Religious pluralism is one example of such Western theologies. This dilemma is particularly felt in the Christian communities of Korea and Africa, who like most other Third World countries have a particular difficulty adapting Western theology to their cultures.

The dilemma of religious pluralism confronts us with the question of culture and the role it plays in contextualising the message of the Gospel. Niebuhr presents this dialectically in terms of culture being rather a help than a hindrance in the process of engaging with the Gospel message ${ }^{2}$. Conn (1984:202) succinctly encapsulates the cultural dilemma: 'The point, after all, is how to do justice to the culture-boundness of human beings on the one hand and to the freedom from culture-boundness of God and His Word on the other, while recognizing the continuous engagement of that free Word of God as it is contextualized within human cultures'.

Often the greatest measure of clarity can be established using a method of juxtaposition. Allan R Culpepper (1998:300-303) presents a view of this culture-polemic, which stands in direct opposition to the view put forward in this article. A critical look at his standpoint will illume the thesis of this article. Culpepper (1998) posits that culture can be used as an effective medium to further the message of Jesus Christ and maintains that the gospel does not contrast any culture. Culpepper cites Jonsson and Hugo H Culpepper in putting forward his argument.

Firstly, Jonsson with his concept of the Wisdom tradition insists that the Gospel can be pluralistic regardless of any culture:

Wisdom belongs to the diversity of human pluralism, necessitating a pluralism in theological expression in the prolongation of the mystery of the incarnation, i.e. God becoming a human being absorbed into the cultures of all people of the world. Here there is a paradox in faith between the particularity of the Jesus of Nazareth and the

2 All references to culture found in this article should be understood in terms of the following definition: culture is in essence a comprehensive set of symbols and narratives to which a certain group of people have, and will continue to, attach meaning. 
universality of the cosmic Christ, the 'logos' of God (in Culpepper 1998:302).

Jonsson's view serves as a foundational premise for Hugo Culpepper's line of argumentation, (1992:302): 'Just as the Logos brought a saving knowledge of God to Abraham, Moses, and Isaiah, so the Logos continues to speak to persons through other religious traditions as part of God's effort to draw all people to a knowledge of God'. It is therefore apparent that Jonsson's contribution to Hugo Culpepper's view resides in his treatment of wisdom as a universal/cosmic phenomenon, which finds expression in Jesus. This understanding gives way to Hugo Culpepper's all-inclusive interpretation of Logos Christology. $\mathrm{He}$ asserts that Logos Christology comes to fruition in the lives of those who subscribe to other faiths, because it implies that God can be revealed within all religious traditions through the mediation of the cosmic Christ (1992:302).

Allan Culpepper turns to the insights of Hugo Culpepper to cement this broad understanding of revelation. Hugo Culpepper (1992:85-87) refutes the exclusivist approach to revelation by offering his reinterpretation of Ac 4:12. The main thrust of his argument centres around the phrase 'being saved'. He argues that salvation should not be conceived of as an objective statement regarding one's status. Instead he favours a salvation hermeneutically grounded in a personal self-concept informed (or transformed) by one's relations with God and others. This relational focus is carried into his understanding of Christ as the Logos: 'If there is a God beyond all gods, surely he uses every culture, all the differing religious traditions, even all history in seeking to get through to as many people as possible and bring them voluntarily into relationship with himself' (Hugo Culpepper as cited in Allan Culpepper 1998:303).

Allan Culpepper draws on the postulates of Jonsson and Hugo Culpepper in revising the exclusivist nature of the Fourth Gospel. He argues that the exclusivist claims should be interpreted against the backdrop of revelation, since 'the revelation that came through Jesus Christ is the same as that which is universally present in the Logos' (Hugo Culpepper in Allan Culpepper 1998:302). Culture is therefore seen by Allan Culpepper as vehicle by which God reveals himself to all people. 
This understanding of culture gives rise to the suggestion that religious pluralism be accepted. This suggestion becomes problematic when one is confronted with the question of ancestor worship as an element of religious pluralism. There are two options in this dilemma: either ancestor worship must be regarded as a cultural heritage or it must be seen as a religious phenomenon. The very nature of this question has led to a great deal of controversy.

There has been a wide spectrum of responses to this issue. Allan Culpepper's understanding of culture represents one extreme in this spectrum of debate. His hypothesis would deem ancestor worship to be a cultural phenomenon, which will not hinder the realization of the Gospel message. This article will represent the antithesis to Allan Culpepper's view. Thus, the purpose of this article will be to clarify the fact that ancestor worship is not a social function, relative to particular cultures, but rather a religious phenomenon. The leading hypothesis is therefore that ancestor worship falls within the circuit of idolatry.

The frame of reference within which this article is written is that of a Protestant theological perspective. This perspective has been born out of my social context within the Third World. An examination of the situation regarding ancestor worship in these two contexts, African and Korean, will follow. A theological appraisal of ancestor worship will then be undertaken. The final section of this article will offer a response to the dilemma of contextualization in relation to kerygma.

\section{ANCESTOR WORSHIP IN AFRICA}

\subsection{African situation of ancestor worship}

I am indebted to the work of Anderson (1993) with regard to the situation of ancestor worship in Africa. Anderson's paper is based on information gained from extensive field research on this matter conducted in Soshanguve, Pretoria between 1990 and 1992 (1993:26). He classifies African Christians into three types of Pentecostal churches in relation to the practice of ancestor worship or veneration: The Pentecostal church, the indigenous churches and the Zion Christian church. After discussing these churches members' views on ancestor worship, he comes to the conclusion that most Christians do not think ancestor worship is acceptable due to its religious function. 
The weight of evidence of this research points to the fact that for most members of these churches the ancestor cult is rejected. Ancestors do appear to Christians, but their response as believers is usually to reject the 'visitation.' The 'ancestors,' they believe, are not ancestors at all, but demon spirits which need to be confronted and exorcised or idols which need to be spurned for they only lead to further misery and bondage (1993:37).

Conversely, some African scholars, for example Mbiti (1969:108), Dzobo (1985:340) and Becken (1993:338) still believe ancestor worship must be accepted, despite it being a religious phenomenon. The grounds for this line of thought can be traced to the foundation belief that African kin-groups are in fact communities including both the living and the dead. Ancestors retain a functional role in the world of the living, namely a social function, specifically in the life of their living kinsmen. The Kenyan Anglican theologian John Mbiti (1969:25) coined the term the 'living dead' with reference to ancestors. Triebel $(2002: 188)$ further elaborates on this concept. He explains that the 'living dead' are indeed those who are physically deceased, yet they remain part of the community in and through their memory. This involvement extends to all spheres of their descendants' lives and in this way physical death does not imply a total death.

The communal nature of African-kin groups is characterised by a great degree of inter-dependence. The individual locates identity within the group. Mbiti (1969:108) encapsulates this relationship with the following words: 'I am, because we are; and since we are, therefore I am'. This is the same principle as that known as ubuntu amongst South Africans. The community takes precedence over the individual, and this community includes both the living and the dead.

The cultural dilemma presents itself here in full force. Should ancestor worship be treated as a social phenomenon, i.e. seen from a cultural perspective? Or alternatively, should it be dealt with from a theistic perspective and therefore treated as a religious phenomenon?

\subsection{Ancestor worship as a social phenomenon}

Becken (1993:336) argues that ancestor worship should be seen as having a strong social function. The main premise for his argument is grounded in the communal identity of the African people. The 
communion of the family is not altered by death, so that deceased family members still form an integral part of the family, and therefore still bear upon the group identity. Becken exercises caution in referring to this communal emphasis, which he asserts does not imply disregard for the individual. On the contrary, the individual and the group share in a relationship of reciprocity. The individual carries a responsibility towards the group, and the group holds the individual. This relationship is not diminished by death.

For Becken, when one understands the nature of this communal identity, ancestor worship can only be seen as fulfilling a social function, which serves to contribute to this communal identity. The practice of ritual killing is one example used by Becken to illustrate this point (1993:336). He argues that this act strengthens community bonds for both the living and the dead (ancestors). The deceased family members are still included in the feast by the invitation to participate, while it is the living family members who partake of the feast. This concept of fellowship will be explored in greater depth below.

The Nigerian theologian Bolaji Idowu (1973:186) also believes that ancestor worship cults do not constitute African traditional religion. He says cults are a means of communion and communication between those who are living on earth and those who have gone to live in the spirit world of the ancestors. Vilakazi (1986:76) says that ancestor cults are based on a kinship principle extended to the dead or to the invisible members of the family. Catholic Cameroonian theologian Jean-Marc Ela (1987:33) shows that offering to the ancestors is a sign of respect, symbolising the continuity of family. This practise is thus simply an expression of the command to children to love their parents. Thus ancestor worship cults are purely an anthropological reality and not related to religion at all. But this view does not take into account the fear of the ancestors that is part of the ancestor cult.

Noah K Dzobo (1985) also promotes the cultural approach to ancestor worship. He addresses the widely held misconceptions regarding the theological and moral significance of ancestor worship, and ascribes these misconceptions to an impoverished understanding of what an ancestor actually is. He sees in the concept of 'ancestor' not so much the idea of a god or a demigod, but on the individual level, a moral example. He explains that the Akan and Ewe terms for 'ancestor', namely nananom or togbuiwo, are titles 
indicative of exemplary morality (1985:334). These titles are earned during one's life and remain with one in death. This conception of 'ancestor' does not necessarily entail a supernatural being as such, but an example of a moral life. According to Dzobo (1985:334) God is seen as the supreme moral example, the 'Grand Ancestor'. This means that God is part of society, yet distinct in supremacy. This superior moral example provides a maxim for others to follow.

Dzobo's other point of emphasis relates to the symbolic nature of the ancestors. According to him the ancestors are not representations of actual persons, but rather 'symbolic representations', of an ideal of societal life (Dzobo 1985:335, my emphasis). It would seem that Dzobo sees the ancestors as symbolically representing an ideal worldview. The essence of this worldview is a creative and fertile participation in life. The creative element is illustrated in the ancestor statues, which depict fertility as a central theme (1985:335). This view also serves to stress a strong participatory element. 'The African through his participation in the ancestor cult sees himself as a part of the creative power of life that transcends himself yet he is an integral part of this dynamic creative power of life...' (1985:335).

It should be noted that Dzobo's term 'worldview' is in fact a loaded term. This term takes on a distinct religious flavour with his analogy between '...the African conception of the relationship between God and man...' and the 'Johannine and Pauline conception of the relationship between Christ and the believer' (1985:335). Dzobo goes on to assert that it is through the African concept of ancestors that a deep theological truth is revealed. The participatory facet means that God participates with human beings, thereby extending the availability of 'his creative power/spirit' (1985:335).

It is precisely this point which serves as the catalyst for the author's rejection of the cultural approach to ancestor worship. God indeed shares his creative power, not through the ancestor world but through his Spirit. It is in participation with this Spirit and not a 'creative force' as such or with the ancestors that we share in God's creative life. This will be elucidated in section four.

\subsection{Ancestor worship as a religious phenomenon}

As has been illustrated above, ancestor worship can have a social function, which emphasizes kinship and communal identity. Seen from this cultural perspective, ancestor worship can be said to 
emanate from within the family, solidifying the communal aspect inherent in the family. Theo Sundermeier locates this social function as an 'eminent social - and community - stabilizing function' (1973:146). While this social function may be apparent, it should not be viewed in isolation, because ancestor worship also has a particular religious function.

The term 'religious' requires a preliminary note: it refers in this paper to a strict 'theism', which marks belief in the one God (Triebel 2002:193). So if African ancestor worship is described in terms of a religious phenomenon, the necessary implication is that the ancestors acquire their own independent religious functions. This is then incompatible with the Christian belief in one unrivalled God (Triebel 2002:193). The religious function of ancestor worship requires careful attention.

Mbiti (1969:83) deals with the religious function by explaining the role of the ancestors. According to him, they hold power to 'cause or prevent misfortune'. This power results in a response of either fear or expectancy. This response is indicative of the fact that the African people must be fully convinced of the ancestors' role as intermediaries and mediators whose responsibility it is to invoke a blessing upon their descendents in and through their prayers to God. This conviction asserts that the ancestors are seen as Supreme Beings, able to form a bridge between the individual human and God.

The particular religious function of ancestor worship can be further explained by examining the attitude of those who call on the ancestors (Balz 1995:8). Treibel (2002) posits that within the worshipers' call there is an anticipation and expectation for a fullness of life to be delivered by the ancestors. This expectation reflects the perceived power of the ancestors to mete out reward or punishment. This leads one to question whether the ancestors have not taken the position of God in terms of Provider and Helper. There is no doubt that ancestor worship fulfils a pivotal role in African religion (Sundermeier 1988:143, 159). The religious function of ancestor worship is therefore explicit.

A close critical analysis of Anderson (1993) reveals three further motivations for ascribing a religious function to ancestor worship. The first motivation stems from the differing definitions of the ancestors offered by Anderson and Mbiti. While Mbiti 
(1969:334) holds that the ancestors are still part of the living community, 'the living dead', Anderson's definition suggests a far greater divide between the dead and the living, 'The ancestors are believed to be those who have died, existing in some usually undefined and unknown place to which the living have no access' (1993:27, my emphasis). This distinction made by Anderson implies a religious facet to ancestor worship. The ancestors would have to acquire 'god status' in order to be able to still exercise control over the separate realm of the living.

The second motivating factor deals with the manner in which the ancestors reveal themselves. 'Ancestors reveal themselves mostly through dreams, but also - though less frequently - through (day) visions and through diviners' (Anderson 1993:27). The mere presence of the term 'revelation' already evokes a religious picture. One cannot ignore the similarities in the way the ancestors reveal themselves and the manner of revelation employed by God or gods. Although John Janzen (1991 in Becken 1993:338) suggests that 'the diviner would appear to be an indigenous psychotherapist', he cannot evade the fact that both through the diviner or through dreams the living seek to make contact with the ancestors in order to receive revelation.

The final motivation for arguing for this religious function resides in the demand made upon the descendents by the ancestors. The expectation is that any kind of wrongdoing by a descendant should be rectified by means of a sacrificial offering. 'The ancestors must be appeased with gifts, such as the ritual killing of a cow, goat or chicken, a dish of porridge, the pouring out of a libation of sorghum beer, and other rituals as demanded by the ancestors themselves' (Anderson 1993:28). If descendents do not comply with these demands, the ancestors will withdraw their protection and this would in effect bring harm to the descendents (Anderson 1993:29). Does this form of appeasement-by-sacrifice not preclude a merely social type of veneration?

Thus far the brief discussion has presented a polemic between the social versus the religious function of ancestor worship. These two functions are not mutually compatible. A choice needs to be made. This article favours Anderson's 'theistic' perspective, which emphasises the religious function of ancestor worship. This will serve as the basic premise for the argument of this contribution, 
which stands in favour of a rejection of ancestor worship. This argument will be further developed in section four.

\section{ANCESTOR WORSHIP IN SOUTH KOREA}

In South Korea, as in Africa, ancestor worship can be viewed as either a social or a religious phenomenon according to either cultural or theistic perspectives. The concept of ancestor worship in South Korea is somewhat similar to that in Africa. Just as the veneration of the ancestors in Africa is often seen from a social perspective, so too is the concept of 'filial piety' seen as a social phenomenon in Korea, while shamanism is viewed as more of a religious phenomenon. A full theological appraisal of ancestor worship will follow later, so this section will be limited to a descriptive analysis of the historical context in Korea regarding ancestor worship, with special focus on Confucianism and Shamanism.

\subsection{Confucian context}

The Confucian context in Korea has been covered very well by $\mathrm{M} \mathrm{H}$ Kim (1984) and Y C Ro (1988). Kim illustrates the religious context into which Christianity was introduced in Korea. Confucianism dominated this context, not only as civil religion, but also as ethical maxim and broad socio-political policy. Korean culture was deeply influenced by Confucianism, the central tenets being 'the life principle of patriotic loyalty and filial piety' (Kim 1984:236). Ro also emphasises the importance of the Confucian tradition. He argues that the religious significance of this tradition is manifest in the ethical foundation it has provided for ancestor worship, which has contributed to the long-standing preservation of the practice of ancestor worship in East Asian countries (Ro 1988). Ro echoes Kim in designating the concept of 'filial piety' as central to Confucian ethics. It therefore follows that ancestor worship in Korea cannot be understood apart from the Confucian tradition, and more specifically, the concept of filial piety or loyalty. The question of how this relationship is to be understood (religious or social) depends on how one interprets the practices of the tradition. Historically there has been much debate on the issue of filial piety.

This debate has centred on the two sides of filial piety, namely the ethnic-socio traits, and the religious traits. This debate has been one of degree rather than a call for exclusivism as it is impossible to separate these two facets. 
Ro locates the function of ancestor worship (filial piety) along the lines of an ethnic-socio capacity. He argues that filial piety should be understood as the act of serving one's parents in both life and death. Within the Confucian tradition filial piety is inextricably linked to moral fibre. Respect and veneration for the ancestors affirms a human's identity as a moral being. This identity is further enhanced as filial piety brings the person back to the 'roots of existence' (Ro 1988:13), a journey back to his origins that brings forth an attitude of gratitude. In this light ancestor worship can be seen as an outward ritual of the moral significance of filial piety.

Ro's concept of filial piety thus shares common ground with the concept of ancestor veneration being put forward by Mbiti and Dzobo. As explained above, Dzobo asserts that an ancestor, a revered moral example, exhibits exemplary moral character during his life and even retains his status in death. Just as Ro explains ancestor worship in the light of the moral significance it holds (in filial piety), so too does Dzobo. Mbiti also emphasises the societal life as being the realm of the ancestors' influence. Holding as he does that the ancestors are still part of the living community, 'the living dead' (Mbiti 1969:334, Idowu 1973:186, Vilakazi 1986:76, Ela 1987:33). Ancestors retain a functional role in the world of the living, namely a social function, specifically in the life of their living kinsmen. This social function intersects with Ro's emphasis on the moral significance of the ancestors.

Kim, on the other hand, then moves to the other end of the spectrum and emphasises the religious function of ancestor worship. $\mathrm{He}$ argues that filial piety is distinctly religious because within the Confucian tradition filial piety is a prerequisite in following the 'Mandate of Heaven' (1984:236). Filial piety is therefore seen as a bridge which unites Heaven and humanity. According to the Confucianist tradition, death separates body (form) and soul. Ancestor worship serves to reunite the two and bring harmony.

Kim further elaborates on this point by citing Yi Yulgok, a saintly Confucian scholar (1536-1583). Yulgok locates his argument for the primacy of ancestor worship in the Confucian concept of the soul's existence. This concept holds that the soul only exists in acts of sincere devotion. Death impinges upon the soul's devotion. Ancestor worship in its acts of remembrance and devotion, thus elevates the soul (Kim 1984:237). 
Confucianism as a religious phenomenon is now obvious. Yi emphasises the necessity of ancestor worship for Korean people on the basis of this religious capacity. Within the context of these discussions it seems reasonable to imagine that filial piety was contrary to its original intention as reverence or veneration (Kim 1984:237). Kim's remarks cement this postulate, saying '...it was again commonly believed that the deceased souls themselves, not the Heaven, could be able to bless their descendants' (1984:237). The deceased souls are not simply objects of veneration and respect, but in fact objects of worship, or deities.

This religious aspect now appears so obvious that Ro's omission of this religious aspect must be questioned. Ro's definition of ancestor worship hinges upon filial piety carrying a purely moral significance. This relates closely to the concept of ancestor worship, which was prevalent at the time of Confucius. During this period the cosmological and ontological facets of ancestor worship were grounded in the moral significance thereof. Chan stresses the shift from the personal form of Ti (Lord) or Shang Ti (the Lord on high) to an impersonal form of moral power. The ancestors exerted their influence 'through their moral example and inspiration' (1963:4). Confucianism played a moral more than a religious role. This is precisely the point of departure used by Ro.

\subsection{Shamanistic context}

The above discussion reveals the essence of ancestor worship in current Korean society to be grounded in filial piety. This filial piety can be interpreted as having an ethnic-socio function (if Ro's hypothesis is to be assumed). The concept of filial piety in Korea, then, is quite similar to that of the veneration of ancestors in Africa.

There is nevertheless a distinctly religious function inherent in ancestor worship. This religious function exhibits itself in the supernatural powers attributed to the ancestors. The ancestors take on supernatural qualities as they are viewed as possessing power, even in death. This then makes ancestor worship a religious act, which in turn takes on the connotations of idolatry within the Christian perspective. For example, the dead are believed to have the same interest in the affairs of the living as when alive. This interest means that the ancestors will intervene in the course of events for the welfare of the family or tribe. The dead are therefore able to protect their relatives and bring them prosperity and success in their 
undertakings. This providence is then 'repaid' in ceremonial veneration and sacrifice. Otherwise, the deceased may bring sickness, storms, calamities or other misfortunes upon the living. Thus it is evident that the incentives of ancestor worship are not only filial piety, but also fear of the deceased spirits.

Ro's focus on the moral significance of ancestor worship does not exclude the religious function. He locates this religious function within the realm of Shamanism (1988:11). He argues that Shamanism is the oldest form of religious belief in Korea, and that its influence has in no way subsided. On the contrary, it has been incorporated into all the major religions in Korea. The basic focus of Shamanism deals with the role of the Shaman. The Shaman is able to resolve all the disunity and lack of harmony caused by 'conflicts... disease, a loss of life, immature death, calamities by unknown reasons...' (Ro 1988:11).

Shamanism and animism had an influence on ancestor worship in both Korea and Africa. This influence manifests in the common $\mathrm{mind} /$ body dualism. Similarly, it is worth noting that the concept of immortality mentioned by Mbiti (1969:83) is also found in the Korean context.

Viewed in this light, the definitive components of ancestor worship are threefold: a close relation to Shamanism, a particular concept of immortality, and the principle of ancestor veneration. The common factors of ancestor worship will be further examined in the next section.

\section{A THEOLOGICAL APPRAISAL OF ANCESTOR WORSHIP}

Section three illustrated the three common features of ancestor worship shared by both the African and Korean contexts. They are: conventional superstition (shamanism in Korea and animism in Africa), belief in immortality and ancestor veneration (filial piety in Korea). These factors need to be assessed theologically, irrespective of whether the focus is of a social or religious nature. A theological assessment will reveal the severe incompatibility of ancestor worship and Christianity.

\subsection{Criticism of conventional superstition}

Addison (1938:110-21) provides a valuable starting point in this theological analysis when he affirms the link between a missionary 
approach and a thorough understanding of the nature and origin of other religions.

The task of establishing the nature and origins of ancestor worship is not a simple one. Gates (1979:199) offers an answer to this question, which sees the kernel of ancestor worship to be rooted in "the Powers" which were overthrown in the death and resurrection of Christ'. These powers will see their end at the parousia. In the resurrected Christ these powers are defeated. They are subsequently under His dominion. This victory is a shared reality for Christians today. Through Christ, they are able to confidently deny any so-called hold which these powers may try to exert on people (2 Cor 2:14-17) (Lim 1984:228). The animistic aspect of ancestor worship is thus challenged in the New Testament by Christ's resurrection and triumph over these powers (Col 2:15). Christ has already claimed victory. This means that this position of victory and security is an ontological reality for 'all who are indwelt by the Spirit of the mighty Christ' (Lim 1984:229). This position of victory allows the believer to fully internalise the promise of the New Testament: 'No created power in heaven, earth, or under the earth is able, henceforth, to separate those who are "in Christ" from the love of God (Rm 8:39)' (Lim 1984:229).

The fear of the ancestors is a common motive in ancestor worship. This fear is no longer a reality in the life of a believer, Christ ushers in a whole new way of relating to matters of culture, and this new approach is now one of liberation rather than fear.

Gates calls attention to the teaching of the Apostle Paul with regard to resisting the powers. Seen from this Pauline perspective the powers are deemed useless. They are revealed for precisely what they are, 'self-vaunting intelligences desirous of being gods, not servants'. With their guises gone their true deceptive nature is revealed $(\mathrm{Rm}$ 8:35; Col 2:20, 21). These powers are utterly useless, as is especially obvious when they are seen in relation to Christ. Any claim they may have made to greatness is redundant in the light of Christ's true glory (Ac 4:28).

The religious element of ancestor worship is for the most part grounded in this animistic aspect. The related aspects of eternal life, veneration, and filial piety will now be dealt with. 


\subsection{Criticism of the concept of immortality}

One of the important points of difference between the African ancestor-worshipping view and the Christian faith concerns their differing views of death. The African view holds that death is simply a period of transition followed by a mode of existence only slightly different from one's earthly existence. The biblical perspective on death is vastly different. According to biblical witness death signifies a complete break with earthly existential realities such as time and space. This new mode of existence is completely different to earthly existence, and the release from spatial and temporal barriers facilitates a closer union with God (Schwarz 1979:172).

In both African and Korean ancestor worship there is the belief that one can have communion with the living spirit of the departed (Lim 1984:230). This belief necessitates careful theological consideration. Certainly biblical texts like Ecclesiastes 9:4-10 stand in opposition to this belief: 'the dead do not know anything, nor have they any longer a reward, for their memory is forgotten. Indeed their love, their hate, and their zeal have already perished, and they will no longer have a share in all that is done under the sun... There is no activity or planning or wisdom in Sheol where you are going'. This text makes it very difficult to justify any kind of interaction between the living and the dead. Beyerhaus (1966:137-145) expands on this scepticism regarding the perceived relationship between the living and the dead. He argues that there is unanimity amongst both Jewish and Christian scholars (Church Fathers included) regarding the danger of pursuing any kind of communication with the dead. This danger lies in their assertion that the spiritual forces at work in such activities are 'not the souls of the departed but the power of the fallen angels or demons who are masters of disguise.'

\subsection{Criticism of the role of dead ancestors}

Earlier the role of dead ancestors was explored, specifically in relation to Mbiti's (1969:25) view which regards them as the 'living dead'. This is echoed in Uchenu's (1976:292) concept of the ancestors possessing 'powers which can cause or prevent misfortune'. Dzobo (1985) further extends this influence to the realm of morality in his concept of the ancestors as exemplars of perfect morality. These views collectively imply a dependence by living descendants on their dead ancestors. The ancestors are deemed to be powerful agents of moral guidance. Also, the ancestors 
are not simply passive agents of this guidance, but very active in that they are perceived as being able to bring reward or punishment to their descendants. The ancestors are therefore causes of fear and hope.

This relationship of dependence jars with the Christian view, which reserves this role of guidance solely for the Holy Spirit. While the ancestors are not explicitly referred to in terms directly synonymous with the Holy Spirit, the lack of any kind of strict distinction is troublesome nevertheless. There does appear to be a dangerous confusion regarding the intermediary role of the Holy Spirit as opposed to that of the ancestors.

The Holy Spirit alone fulfils a salvific intermediary role. Louis Berkhof (1941:473) emphasises the role of the Holy Spirit as being the 'efficient cause of regeneration'. This regeneration involves a change in the spiritual condition of the person. This change is effected solely by the work of the Holy Spirit, and lies completely beyond the scope of human beings to effect this change independent of the Holy Spirit (Ezk 11:19; Jnh 1:13; Ac 16:14; Rm 9:16; Phlp $2: 13)$. The dependence that is felt toward the ancestors is therefore misplaced. The ancestors cannot fulfil the intermediary role that is reserved for the Holy Spirit.

Jesus touches on the role of the dead when he deals with the question of the Resurrection (Mt 22:23-33; Mk 12:18-27; Lk 20:2740). A group of Sadducees are debating what the role of the dead will be in the afterlife after the resurrection. Hagner (1998:640-642) interprets Jesus' response as suggesting that the future existence will be both continuous and discontinuous with the previous existence. The continuity will reside in the fact that we will have bodies and the discontinuity in the fact that these bodies will be totally new and different to what we have known before. The concept of ancestors is incompatible with this Christian vision of the role of the dead. The ancestors do not allow for the Christian promise of a complete new creation.

\section{CONCLUSION}

It can be concluded, therefore, from what has been said above, that the function of ancestor worship can be classified into two roles, religious and social. In our discussion of the social and religious implications of ancestor worship, the religious function has been found to feature within the realm of the participant of worship; the 
social (moral) function featured within the realm of the family relationship which even extends beyond death. In addition, ancestor worship has been identified as a threefold composition of conventional superstition, immortality and ancestor reverence. This composite relationship involves each facet functioning within an interdependent framework.

However, I would like to argue that these above -mentioned three factors should be seen as divisible from one another. This will eradicate the common tendency to confuse ancestor reverence in a social role with ancestor worship in a religious role. Keeping the three components of ancestor worship in a tension of divisibility reduces the risk of human interference in this delicate network of interdependence. It is due to the human drive for self-preservation that the boundary between God and the ancestors becomes blurred.

Dunn (1988:114-115) succinctly explains the motivation behind this human tendency. He goes right back to Gn 3:5 and argues that it is this self-same desire to be like God which results in humans making religion a means to self-glorification. Dunn further probes the root cause of this desire to be like God and suggests that it is nothing less than 'the will to power'. Exercising power over others is a characteristic of the human condition; Dunn argues that this stems from 'a perversion of the creature's basic instinct to acknowledge God and to acknowledge dependence on God.'

This 'perversion' of the urge to worship God is clearly demonstrated in the practice of ancestor worship. The image of an ancestor is not an idol in itself; rather it becomes an idol when it is made the object of worship. This point leads us further into a consideration of the first and second commandments of God, which are conceived as the cornerstones of the Judeo-Christian idea of monotheism (Ex 20:3-6). From what has been discussed, we can conclude with a high degree of probability that ancestor worship should be viewed as idol worship.

In conclusion, it is clear that ancestor worship is a form of misdirected religion. This means that when kerygma is applied in a situation of contextualization, religious pluralism should not be included. The goal of all kerygma is to proclaim Jesus Christ as Saviour. This goal becomes distorted when religious pluralism is tolerated. 


\section{Consulted literature}

Addison, J T 1938. The Changing Attitude Toward Non Christian Religions. International Review of Missions 27, 110-121.

Anderson, A 1993. African Pentecostalism and the Ancestor Cult: Confrontation or Compromise? Missionalia 21(1), 26-39.

Balz, H 1995. Where the Faith has to Live: Studies in Bakossi Society and Religion. Part II: The Living and the Dead. Berlin, Germany: Dietrich Reimer.

Becken, H J 1993. Beware of the Ancestor Cult! A Challenge to Missiological Research in South Africa. Missionalia 21(3), 333-339.

Berkhof, L 1941. Systematic Theology. Grand Rapids: Eerdmans.

Beyerhaus, P 1966. The Christian Approach to Ancestor Worship. Ministry 6(4), 137-145.

Chan, W T 1963. A Source Book in Chinese Philosphy. Princeton: Prinston University Press.

Conn, H M 1984. Eternal Word and Changing Words: Theology, Anthropology and Mission in Trialogue. Grand Rapids: Zondervan.

Culpepper, A R 1998. The Gospel and Letters of John. Nashville: Abingdon Press.

Culpepper, H H 1992. Acts 4:12. Review and Expositor 89, 85-87.

Dunn, J D G 1988. The Theology of Paul the Apostle. Grand Rapids: Eerdmans.

Dzobo, N K 1985. African Ancestor Cult: a Theological Appraisal. Reformed World 38(6), 333-340.

Ela, J M 1987. Mein Glaube als Afrikaner: Das Evangelium in schwarzafrikanischer Wirklichkeit. Freiburg: Herder.

Gates, A F 1979. Christianity and Animism in Taiwan. San Francisco: Chinese Materials Centre.

Hagner, D A 1998. Matthew 14-28. Dallas, Texas: Word Books (WBC 33B).

Idowu, E B 1973. African Traditional Religion: A Definition. London: SCM Press.

Janzen, J M 1991. Doing Ngoma: A dominant Trope in African Religion and Healing. Journal of Religion in Africa 21(4), 290-308.

Jonsson, J N Wisdom: The Threshold of God in Human Existence (Forthcoming: to be published in a collection edited by John A L Saunders).

Kim, M H 1984. Ancestor Worship in the Korean Church. Evangelical Review of Theology 8(2), 236-245.

Lim, G E 1984. Christianity Encounters Ancestor Worship in Taiwan. Evangelical Review of Theology 8(2), 224-235.

Mbiti, J S 1969. African Religions and Philosophy. London: Heineman.

Niebuhr, H R 1951. Christ and Culture. New York: Harper. 
Ro, Y C 1988. Ancestor Worship: From the Perspective of Korean Tradition. In Ancestor Worship and Christianity in Korea. Lewiston, NY: Edwin Mellen, 7-19.

Schwarz, H 1979. On the Way to the Future: A Christian View of Eschatology in the Light of Current Trends in Religion, Philosophy, and Science. Minneapolis: Augsburg Publishing House.

Sundermeier, T 1988. Nur gemeinsam können wir leben. Das Menschenbild schwarzafrikanischer Religionen. Gütersloh: Gütersloher Verlagshaus.

Sundermeier, T 1973. Wir aber suchten Gemeinschaft: Kirchwerdung und Kirchentrennung in Südwestafrika. Erlangen: Verlag der Ev.-Luth. Mission.

Triebel, J 2002. Living Together with the Ancestors: Ancestor Veneration in Africa as a Challenge for Missiology. Missiology 30(2), 187-197.

Uchenu, C V 1976. Ancestorcide! Are African Ancestors Dead? In: W H Newell (ed) Ancestors. Hague: Mouton Publishers, 283-296.

Vilakazi, A 1986. Shembe: the Revitalization of African Society. Johannesburg: Skotaville. 